\title{
Gastric response to subcutaneous injection of a gastrin-like pentapeptide
}

\author{
K. G. WORMSLEY, M. P. MAHONEY, AND G. KAY \\ From the Royal Infirmary, Manchester
}

EDITORIAL COMMENT Subcutaneous injection can give reproducible results. When the volume of the injection remained unchanged the response was reduced by continuous intravenous infusion of secretin and by vagotomy.

We have recently reported the effect on gastric secretion of the intravenous infusion of a gastrin-like pentapeptide (I.C.I. 50,123) (Wormsley, Mahoney, and $\mathrm{Ng}, 1966$ ). The present study describes the gastric secretory response to this pentapeptide given subcutaneously, which is compared with the response to the intravenous infusion of pentapeptide and to the subcutaneous injection of ametazole. We also report the effect of secretin and of vagotomy on the gastric response to subcutaneous pentapeptide.

\section{METHODS}

The subjects of this study comprised 18 normal medical students, 22 patients awaiting operation for chronic duodenal ulceration, and a miscellaneous group of six patients, including one with gastric ulcer, one with pancreatitis, and four who were undergoing investigation of abdominal pain. In 12 of the patients with duodenal ulcer, the secretory studies were repeated after vagotomy and pyloroplasty.

After a 12-hour fast, a Ryle's tube was passed into the stomach under fluoroscopic control. A separate Dreiling tube was used to collect duodenal juice during tests involving secretin. Gastric and duodenal contents were aspirated continuously. The volume of gastric contents recovered during 10 -minute periods was recorded. The acid concentration of the gastric contents was measured on a Radiometur $p \mathrm{H}$ meter by titrating with $0 \cdot 1 \mathrm{~N}$ sodium hydroxide to $p \mathrm{H} 7$. Peptic activity was estimated by the method of Hunt (1948).

A standard dose of $6 \mu \mathrm{g}$. per kilogram body weight of pentapeptide (I.C.I. 50,123, Peptavlon) was injected subcutaneously in $2 \mathrm{ml}$. of $0.15 \mathrm{M}$ sodium chloride. In five subjects, the pentapeptide was injected in 2,3 , and $5 \mathrm{ml}$. of saline in random order, to study the effect of altering the volume of diluent. The 'maximal' secretory response to pentapeptide was determined with constant rate intravenous infusion (Wormsley et al., 1966). Ametazole (Histalog) was given subcutaneously in a dose of $1.5 \mathrm{mg}$. per kilogram body weight. To test the effect of secretin on the gastric acid response to sub- cutaneous pentapeptide, five subjects were given secretin (Boots) by continuous intravenous infusion in a dose of 25 units/kg./hour for 40 minutes, before receiving a subcutaneous injection of pentapeptide. The secretin infusion was continued during the gastric response to pentapeptide till the test was terminated.

The highest output of acid during three successive 10-minute periods following the injection of pentapeptide or ametazole is taken to indicate the peak response to the test dose and is recorded in milliequivalents per 30 minutes. The term 'maximal secretory response' refers to the response to constant rate intravenous infusion of pentapeptide and denotes the level of acid secretion achieved when increasing the amount of stimulant produces no further increase in output of acid.

\section{RESULTS}

Stimulation of acid secretion could be detected during the first period following the subcutaneous injection of pentapeptide in 69 of 90 tests available for analysis. Maximal volumes were recorded during the second or third collection period (Table I). Concentration of acid attained maximal values during the third collection period in $52 \%$ of tests. During the remaining 40 to 60 minutes of the test, acid concentration remained constant or increased (by up to $6 \mathrm{mEq}$./1.) in 24 of 40 subjects despite a decrease in the volume of aspirated juice. In the other 16 subjects, the concentration of acid decreased as the volume fell (by as much as $16 \mathrm{mEq} . / \mathrm{l}$.).

The output of acid was greatest during the third collection period in $68 \%$ of tests (Table I). Acid secretion maintained a fairly constant plateau during at least three successive collection periods in $82 \%$ of tests, the output of acid during the individual periods varying by less than $10 \%$ from the mean of the three periods. In $8 \%$ of tests acid output showed a different pattern. Following a delay in the acid response, secretion started during the second collection period 
TABLE I

MAXIMAL RATE OF SECRETION FOLLOWING SUBCUTANEOUS PENTAPEPTIDE

\begin{tabular}{cc} 
10-Minute Period after Injection & Percentage of Tests \\
\hline 2nd & 46 \\
3rd & 44 \\
4th & 7 \\
5th & 2 \\
Maximal concentration of acid & \\
2nd & 11 \\
3rd & 52 \\
4th & 25 \\
5th & 11 \\
& \\
Highest acid output & \\
2nd & 23 \\
3rd & 68 \\
4th & 16 \\
5th & 2 \\
& \\
2nd-4th & 69 \\
3rd-5th & 31
\end{tabular}

(and third, in one subject), rapidly reached a peak value and then equally rapidly tailed off. The response in three of these subjects followed a more usual pattern on other occasions.

The median value of the acid output was 16.8 mEq./30 minutes in 18 normal male subjects and $22.4 \mathrm{mEq} / 30$ minutes in 20 male patients with duodenal ulcer. All but one of the normal subjects secreted less than $20 \mathrm{mEq}$. $/ 30$ minutes while the patients with duodenal ulcer tended to secrete more than this (Fig. 1). The two female patients with duodenal ulcer secreted less than $20 \mathrm{mEq}$. in 30 minutes.

The output of pepsin, like acid, was greater in patients with duodenal ulcer than in normal subjects, reflecting the greater volume of gastric juice secreted by patients with ulcer (Fig. 2).

EFFECT OF DILUENT VOLUME (DEPOT EFFECT) When $6 \mu \mathrm{g}$. per kilogram of pentapeptide was given subcutaneously in increasing volumes of $0.15 \mathrm{M}$ sodium chloride, the magnitude of the gastric response decreased significantly in four of the five subjects. Thus, the acid output after $6 \mu \mathrm{g}$. per kilogram pentapeptide in $2 \mathrm{ml}$. saline was significantly greater than the response to the same amount of pentapeptide in $3 \mathrm{ml}$. saline, which in turn was significantly greater than the response to $6 \mu \mathrm{g}$. per kilogram pentapeptide in $5 \mathrm{ml}$. saline (analysis of variance showed $\mathbf{P}<0.01$ between each pair of volumes). During his series of tests, case 4 developed upper abdominal pain, which lasted about three weeks, probably the result of ingesting alcohol and aspirin. In the three tests during this period, the gastric juice was bloodstained and acid output decreased. As the symptoms
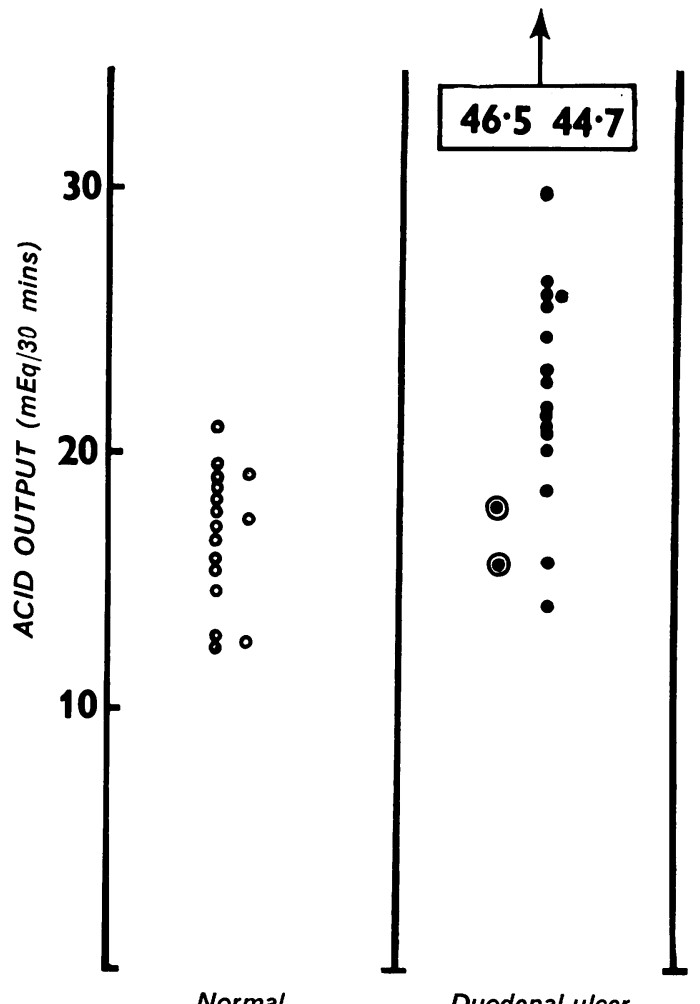

FIG. 1. Acid output following subcutaneous pentapeptide in normal male subjects and patients with duodenal ulcer. The ringed points indicate two female patients with duodenal ulcer.

cleared, blood disappeared and acid output rose. The secretory pattern of case 5 differed from the others, with apparent reversal of the 'depot' effect as well as striking alteration in the relationship of subcutaneous to intravenous response. Figure 3 illustrates these responses.

REPRODUCIBILITY Duplicate tests (Fig. 4) with subcutaneous pentapeptide $(6 \mu \mathrm{g} . / \mathrm{kg}$. in constant volume of saline) gave results within $1 \mathrm{mEq}$. per 30 minutes in eight subjects in whom the tests were carried out on the same morning; in seven subjects in whom the tests were carried out within 14 days; and in one subject after four months. In four subjects, the difference between the two tests (10-day interval in two subjects, 40 and 76 days in the other two) ranged from 1.7 to $4.5 \mathrm{mEq}$. in 30 minutes, representing a variation of from 14 to $27 \%$ of the initial response. The overall correlation was satisfactory ( $r=0.94$ for the 20 subjects). 


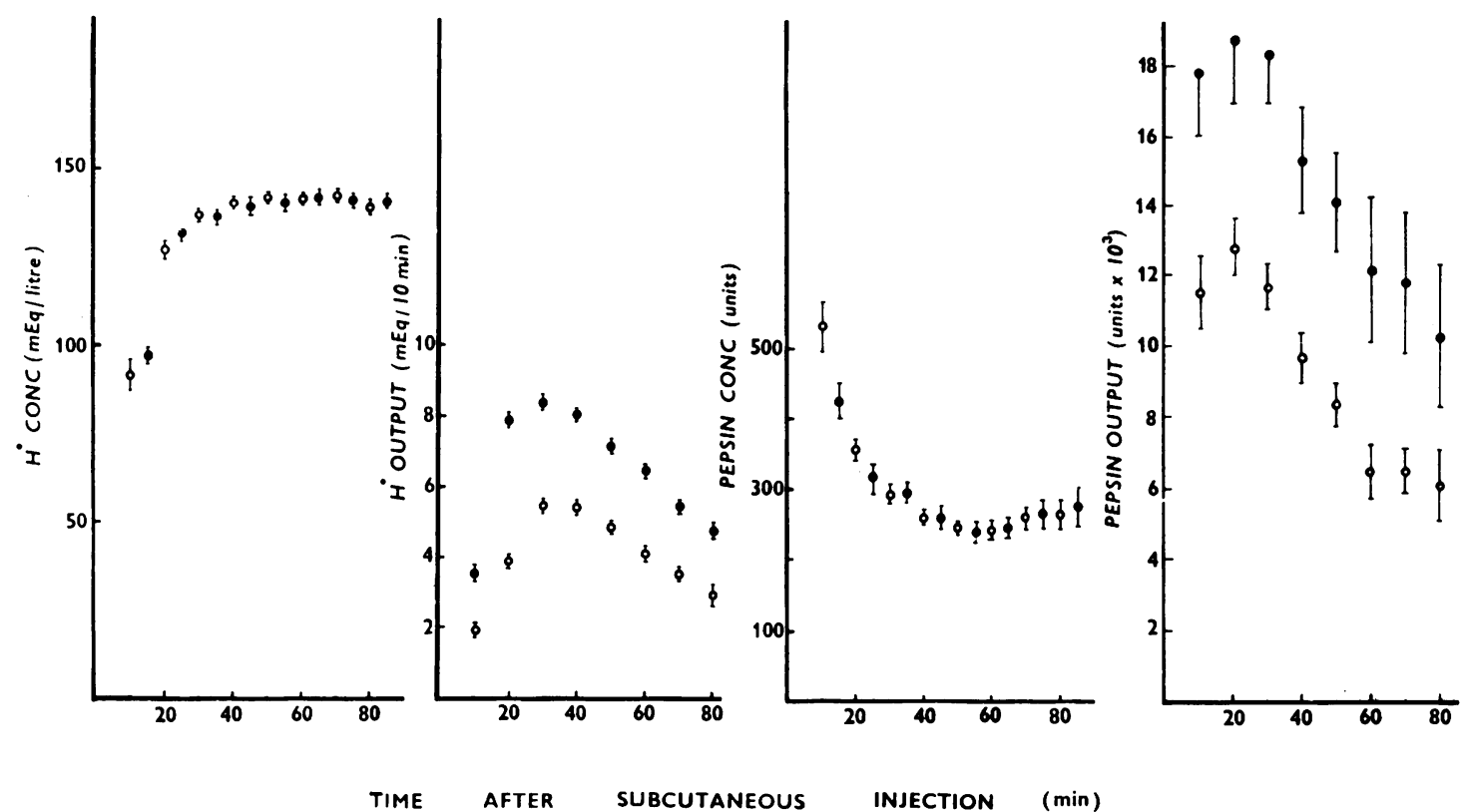

FIG. 2. Mean values and standard errors of acid concentration and output and pepsin concentration and output in 18 normal male subjects and 22 patients with duodenal ulcer during 80 minutes after subcutaneous injection of pentapeptide.

Open circles $=$ normal; closed circles $=$ duodenal ulcer.
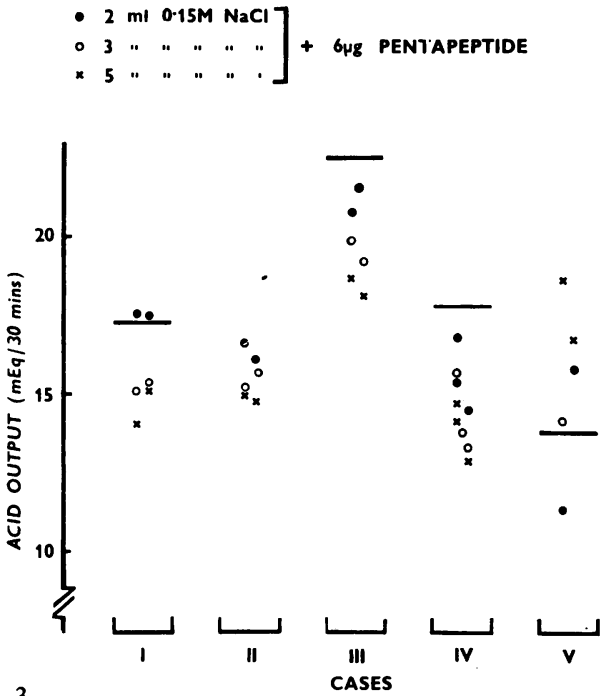

- NORMAL

- duOdenal ulcer

* miscellaneous

FIG. 3 .

FIG. 3. Effect of variation in volume of saline used as diluent for the subcutaneous injection of pentapeptide. Each Roman numeral indicates one subject. Each point indicates one test with $6 \mu \mathrm{g}$./kg. pentapeptide in the appropriate volume of saline. The horizontal bars indicate each subject's maximal response to intravenous pentapeptide (not available in case 2).

FIG. 4. Reproducibility of gastric response to subcutaneous pentapeptide. Each point represents duplicate tests in one subject.

$A=$ response of subject to pentapeptide in 1 and $3 \mathrm{ml}$. saline before effect of depot volume was recognized. $B=$ Case 5, Fig. 3. See text. 


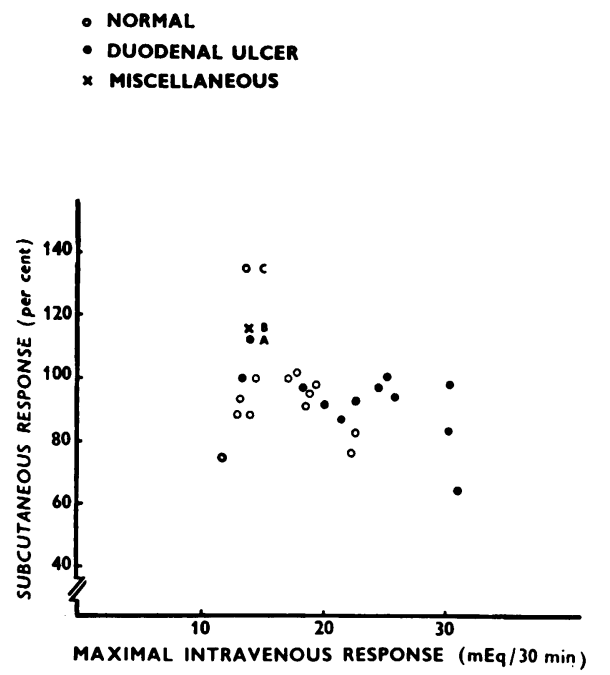

FIG. 5. Comparison of gastric response to intravenous and subcutaneous pentapeptide. Abscissa indicates maximal response to intravenous pentapeptide; ordinate represents response to subcutaneous pentapeptide, expressed as percentage of that subject's intravenous response. Subjects $A, B, C$ described in text. Note that neither type of subject nor size of $I V$ response determines ratio of subcutaneous to intravenous response.

COMPARISON OF SUBCUTANEOUS AND MAXIMAL INTRAVENOUS RESPONSE In 23 of 26 subjects, the response to subcutaneous pentapeptide ranged from 63 to $106 \%$ of the maximal secretory response obtained with constant rate intravenous infusion (Fig. 5). The relationship of the subcutaneous to the intravenous response of normal subjects did not differ from patients with duodenal ulcer. Moreover, the magnitude of the ratio of subcutaneous to intravenous response did not depend on the absolute value of acid output in this series.

The response to subcutaneous pentapeptide was 115,115 , and $136 \%$ of the maximal response to intravenous infusion in the other three subjects, one of whom had intermittent heavy bile staining during her intravenous test, while in the second patient the infusion was discontinued before the test had been completed, because the patient became restless. The third subject was the student whose irregular response to subcutaneous pentapeptide has already been described (case 5, Fig. 3).

COMPARISON OF RESPONSE TO PENTAPEPTIDE AND AMETAZOLE The gastric response to pentapeptide (Fig. 6) was more rapid and tended to be greater, but was less well sustained than the response to ameta-

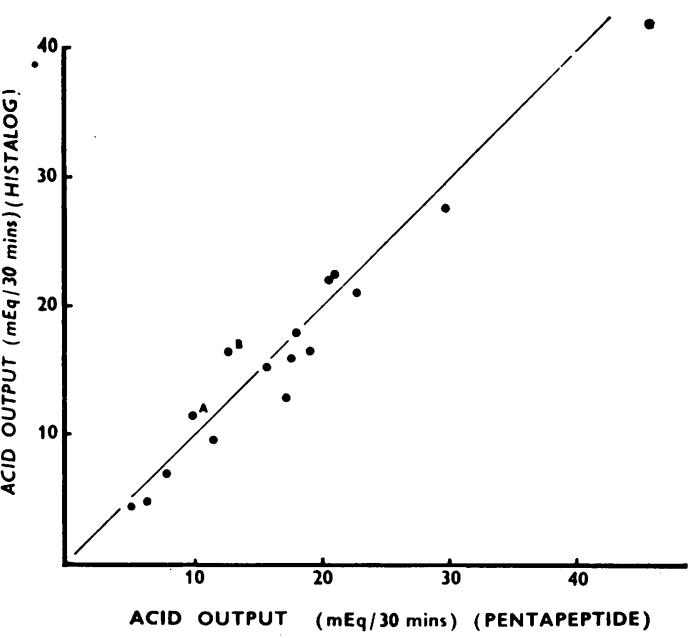

FIG. 6. Comparison of gastric response to subcutaneous pentapeptide (6 $\mu \mathrm{g} . / \mathrm{kg}$.) and ametazole $(1.5 \mathrm{mg} . / \mathrm{kg}$.$) .$ Each point represents results of two tests in one subject. $A=$ Gastric juice heavily bilestained during pentapeptide test. $B=$ Subject nauseated and partially regurgitated tube at the start of the pentapeptide test.

zole (1.5 mg./kg.). The output of pepsin was comparable with the two stimulants.

EFFECT OF SECRETIN ON PENTAPEPTIDE RESPONSE In five subjects in whom the gastric response to subcutaneous pentapeptide was known, a further test with pentapeptide was carried out during intravenous infusion of secretin (25 units/kg./hour) at constant rate. In three tests, reduction in acid response to pentapeptide was noted (Table II). The two other tests were discontinued when hypotensive symptoms developed shortly after injection of pentapeptide. In three of these five subjects (as well as in five others included in a study of pancreatic secretion, to be reported) basal acid output was not inhibited by the large dose of secretin.

EFFECT OF VAGOTOMY In all 12 patients the acid response to subcutaneous pentapeptide fell after

TABLE II

EFFECT OF SECRETIN INFUSION ON GASTRIC RESPONSE TO PENTAPEPTIDE

\begin{tabular}{|c|c|c|c|}
\hline \multicolumn{2}{|c|}{ Acid Output (mEq./30 minutes) } & \multicolumn{2}{|c|}{$\begin{array}{l}\text { Maximal Acid Concentration } \\
(m E q . / l .)\end{array}$} \\
\hline Pentapeptide & $\begin{array}{l}\text { Pentapeptide } \\
+ \text { Secretin }\end{array}$ & Pentapeptide & $\begin{array}{l}\text { Pentapeptide } \\
+ \text { Secretin }\end{array}$ \\
\hline $\begin{array}{r}7 \cdot 7 \\
22 \cdot 7 \\
12 \cdot 7\end{array}$ & $\begin{array}{r}4 \cdot 3 \\
18.4 \\
0 \cdot 2\end{array}$ & $\begin{array}{c}100 \\
142 \\
101\end{array}$ & $\begin{array}{r}114 \\
137 \\
19\end{array}$ \\
\hline
\end{tabular}




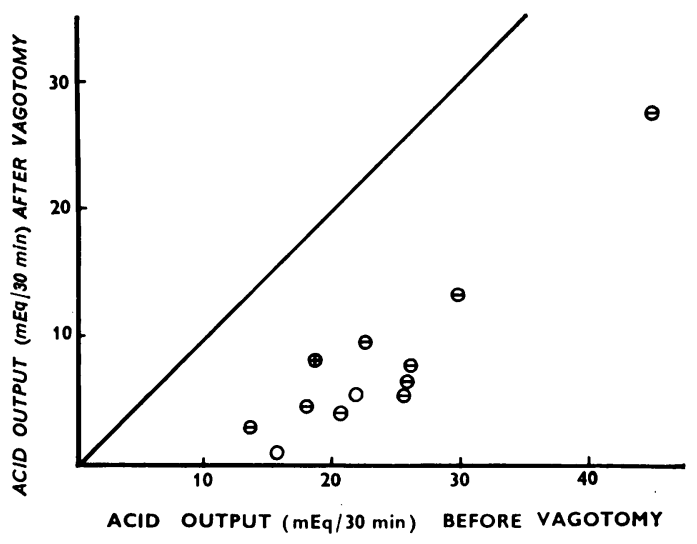

FIG. 7. Effect of vagotomy on the gastric response to subcutaneous pentapeptide. Each point indicates response before and after vagotomy in one subject. Enclosed sign indicates whether postoperative insulin test was positive or negative.

vagotomy (Fig. 7 and Table III). These patients can be divided into two groups: eight, in whom the mean value of maximal acid concentration before vagotomy was $119 \pm 4 \mathrm{mEq}$./l. and four others, in whom the mean prevagotomy value of maximal acid concentration was $145 \pm 3 \mathrm{mEq}$./1. In the former group, the decrease in acid output following vagotomy was significantly greater than in the smaller group $(\mathrm{P}<$ $0 \cdot 01$ ). This cannot be attributed to incomplete vagotomy, since all except one of the insulin tests were negative. In addition to greater decrease in acid output, the larger group of eight patients showed a significantly greater reduction in acid concentration after vagotomy. Moreover, the postoperative output of pepsin was less in this group of patients and there was little or no initial rise in pepsin concentration and output ('washout') after vagotomy. Despite the considerable reduction in acid output in the other four patients after vagotomy, the concentration of acid remained high, 'washout' of pepsin occurred normally, and output of pepsin was normal in three.

In seven of the 12 patients, the maximal gastric response to intravenous pentapeptide was estimated before and after vagotomy. In six of the patients, the observed decrease in maximal acid output after operation was considerably less than the corresponding decrease in the response to subcutaneous pentapeptide (Table IV).

SIDE EFFECTS Side effects to subcutaneous pentapeptide usually developed between four and six minutes after injection and lasted less than a minute. They were similar to those after intravenous pentapeptide and occurred in about a fifth of tests. In no instance was it necessary to discontinue the test. The reactions were mild and consisted of malaise, aching in the muscles, faintness, abdominal discomfort, and nausea. Two subjects retched at this time and one dislodged his tube. One patient developed more severe symptoms of hypotension and bradycardia, which lasted about 10 minutes. The patient subsequently stated that he had reacted to other types of subcutaneous injection in a similar manner. In this test, during the first 20 minutes after pentapeptide, the acid output $(1.6 \mathrm{mEq} . / 20$ minutes $)$ decreased below 'basal' levels $(1 \cdot 3-1 \cdot 5 \mathrm{mEq} . / 10$ minutes) but thereafter resumed at the same rate as during the

TABLE III

GASTRIC RESPONSE TO PENTAPEPTIDE BEFORE AND AFTER VAGOTOMY

\begin{tabular}{|c|c|c|c|c|c|c|c|c|c|}
\hline & \multicolumn{2}{|c|}{$\begin{array}{l}\text { Maximal Acid } \\
\text { Concentration }\end{array}$} & \multicolumn{3}{|c|}{$\begin{array}{l}\text { Acid Output } \\
\text { (mEq./30 min.) }\end{array}$} & \multicolumn{3}{|c|}{$\begin{array}{l}\text { Pepsin Output } \\
(u . / k g .130 \text { min. })\end{array}$} & \multirow[b]{2}{*}{$\begin{array}{l}\text { Insulin } \\
\text { Response }\end{array}$} \\
\hline & $\begin{array}{l}\text { Before } \\
\text { Vagotomy }\end{array}$ & $\begin{array}{l}\text { After } \\
\text { Vagotomy }\end{array}$ & $\begin{array}{l}\text { Before } \\
\text { Vagotomy }\end{array}$ & $\begin{array}{l}\text { After } \\
\text { Vagotomy }\end{array}$ & Percentage & $\begin{array}{l}\text { Before } \\
\text { Vagotomy }\end{array}$ & $\begin{array}{l}\text { After } \\
\text { Vagotomy }\end{array}$ & Percentage & \\
\hline \multirow[t]{2}{*}{$\mathbf{A}$} & $\begin{array}{l}129 \\
117 \\
108^{1} \\
101 \\
116 \\
125^{1} \\
124 \\
129\end{array}$ & $\begin{array}{r}50 \\
95 \\
90 \\
53 \\
36 \\
63 \\
74 \\
104\end{array}$ & $\begin{array}{l}20 \cdot 4 \\
18 \cdot 1 \\
26 \cdot 1 \\
13 \cdot 6 \\
15 \cdot 5 \\
25 \cdot 5 \\
25 \cdot 8 \\
18 \cdot 8\end{array}$ & $\begin{array}{l}3 \cdot 9 \\
4 \cdot 4 \\
7 \cdot 8 \\
2 \cdot 85 \\
1 \cdot 0 \\
5 \cdot 2 \\
6 \cdot 4 \\
5 \cdot 3\end{array}$ & $\begin{array}{r}19 \\
24 \\
30 \\
21 \\
6 \\
20 \\
25 \\
27\end{array}$ & $\begin{array}{l}67 \cdot 7 \\
38 \cdot 7 \\
\overline{25} \cdot 3 \\
\overline{51} \cdot 0 \\
47 \cdot 9 \\
44 \cdot 9\end{array}$ & $\begin{array}{l}\overline{12} \cdot 9 \\
\overline{12 \cdot 4} \\
\overline{20} \cdot 7 \\
27 \cdot 0 \\
23 \cdot 1\end{array}$ & $\begin{array}{l}33 \\
\overline{49} \\
\overline{41} \\
57 \\
52\end{array}$ & $\begin{array}{l}\text { Negative } \\
\text { Negative } \\
\text { Negative } \\
\text { Negative } \\
- \\
\text { Negative } \\
\text { Negative } \\
\text { Negative }\end{array}$ \\
\hline & 118 & 71 & & & $21 \cdot 5$ & & & 46 & \\
\hline \multirow[t]{2}{*}{ B } & $\begin{array}{l}142 \\
139 \\
147 \\
151\end{array}$ & $\begin{array}{l}122 \\
122 \\
125 \\
142\end{array}$ & $\begin{array}{l}22 \cdot 5 \\
29 \cdot 8 \\
44 \cdot 7 \\
18 \cdot 5\end{array}$ & $\begin{array}{r}9 \cdot 6 \\
13 \cdot 2 \\
27 \cdot 5 \\
8 \cdot 4\end{array}$ & $\begin{array}{l}43 \\
44 \\
62 \\
45\end{array}$ & $\begin{array}{l}41 \cdot 3 \\
67 \cdot 4 \\
70 \cdot 5 \\
41 \cdot 0\end{array}$ & $\begin{array}{l}38 \cdot 0 \\
55 \cdot 9 \\
80 \cdot 3 \\
24 \cdot 0\end{array}$ & $\begin{array}{r}92 \\
83 \\
114 \\
59\end{array}$ & $\begin{array}{l}\text { Negative } \\
\text { Negative } \\
\text { Negative } \\
\text { Positive }\end{array}$ \\
\hline & 145 & 128 & & & 48.5 & & & 87 & \\
\hline
\end{tabular}

Each horizontal line of figures represents results from one patient. The figures at the foot of four of the columns indicate mean values; the two groups of patients (A and B) described in the text have been analysed separately. ${ }^{1}$ Denotes salivary contamination. 
TABLE IV

EFFECT OF VAGOTOMY ON GASTRIC RESPONSE TO INTRAVENOUS AND SUBCUTANEOUS PENTAPEPTIDE

\begin{tabular}{|c|c|c|c|c|c|c|c|}
\hline \multicolumn{3}{|c|}{ Intravenous Pentapeptide } & \multicolumn{3}{|c|}{ Subcutaneous Pentapeptide } & \multicolumn{2}{|c|}{$\frac{\text { Subcutaneous } \times 100}{\text { Intravenous }}$} \\
\hline $\begin{array}{l}\text { Before } \\
\text { Vagotomy } \\
\text { (mEq./30 min.) }\end{array}$ & $\begin{array}{l}\text { After } \\
\text { Vagotomy } \\
(\mathrm{mEq} .130 \mathrm{~min} .)\end{array}$ & $\begin{array}{l}\text { After } \times 100 \\
\text { Before } \\
(\%)\end{array}$ & $\begin{array}{l}\text { Before } \\
\text { Vagotomy } \\
\text { (mEq./30 min.) }\end{array}$ & $\begin{array}{l}\text { After } \\
\text { Vagotomy } \\
(\mathrm{mEq} . / 30 \mathrm{~min} .)\end{array}$ & $\begin{array}{l}\text { After } \times 100 \\
\begin{array}{l}\text { Before } \\
(\%)\end{array}\end{array}$ & $\begin{array}{l}\text { Before } \\
\text { Vagotomy } \\
(\%)\end{array}$ & $\begin{array}{l}\text { After } \\
\text { Vagotomy } \\
(\%)\end{array}$ \\
\hline $\begin{array}{l}18 \cdot 6 \\
25 \cdot 2 \\
20 \cdot 2 \\
30 \cdot 6 \\
13 \cdot 6 \\
31 \cdot 3 \\
21 \cdot 7\end{array}$ & $\begin{array}{r}5.6 \\
11.4 \\
11.6 \\
18.6 \\
6.0 \\
7.3 \\
6.1\end{array}$ & $\begin{array}{l}32 \\
45 \\
57 \\
61 \\
44 \\
23 \\
28\end{array}$ & $\begin{array}{l}18.1 \\
25.8 \\
18.5 \\
29.8 \\
13.6 \\
20.4 \\
18.8\end{array}$ & $\begin{array}{r}4 \cdot 4 \\
6 \cdot 4 \\
8 \cdot 4 \\
13 \cdot 2 \\
2 \cdot 9 \\
3 \cdot 9 \\
5 \cdot 3\end{array}$ & $\begin{array}{l}24 \\
25 \\
45 \\
44 \\
21 \\
19 \\
28\end{array}$ & $\begin{array}{r}97 \\
102 \\
92 \\
97 \\
100 \\
65 \\
87\end{array}$ & $\begin{array}{l}79 \\
56 \\
71 \\
71 \\
48 \\
53 \\
87\end{array}$ \\
\hline
\end{tabular}

basal period (1.1-1.5 mEq./10 minutes) for the next 30 minutes. The pepsin output did not differ from basal levels during the first 30 minutes after injection, but then decreased slowly. This test has been excluded from the analysis of this study.

During the secretin infusion, two subjects developed hypotension shortly after the injection of pentapeptide, mild in one and more severe in the other. Both tests were discontinued because of these reactions. This type of reaction has not occurred during a large number of tests where secretin has been infused alone.

\section{DISCUSSION}

In a previous report (Wormsley et al., 1966) we concluded that intravenous infusion of a gastric secretory stimulant was to be preferred to other routes of administration. However, it is easier and less expensive to give subcutaneous injections. In this study, we have shown that the response to subcutaneous pentapeptide $(6 \mu \mathrm{g} . / \mathrm{kg}$. I.C.I. 50,123$)$ is comparable to ametazole $(1.5 \mathrm{mg}$. $/ \mathrm{kg}$. $)$, which had previously been shown to evoke a near-maximal gastric response (Ward, Gillespie, Passaro, and Grossman, 1963). Subcutaneous administration therefore seems adequate to detect achlorhydria and to indicate the magnitude of gastric secretory capacity. However, the gastric response to subcutaneous pentapeptide is a variable proportion of the 'maximal secretory response' to intravenous pentapeptide and for this reason cannot be used to measure 'maximal' gastric response or 'parietal cell mass'. The excellent separation of the secretory response to subcutaneous pentapeptide of normal subjects from patients with duodenal ulcer in this series is due to the fact that only one of the normal subjects secreted more than $20 \mathrm{mEq}$. of acid in 30 minutes, while all except six of the patients with duodenal ulcer secreted more than this. Two of these six patients were the only women included in this group. However, the validity of this observation requires confirmation by data from much larger numbers of normal individuals and patients.

Throughout this study we have expressed the gastric response to subcutaneous pentapeptide as the highest output of acid during a continuous period of 30 minutes. The interpretation of shorter collection periods is made difficult by the rapid rise and fall in acid output which is seen in occasional tests. In over half of our subjects the hydrogen ion concentration remained high as the volume of secretion decreased towards the end of the test, a pattern first noted by Pavlov (1910) and later studied by Hollander (1952), who gave histamine subcutaneously to dogs. In the remainder of our subjects, acid concentration decreased as the volume of gastric juice fell off, as Rosemann (1907) found in sham-fed dogs and as described in human subjects after injection of gastrin subcutaneously (Makhlouf, McManus, and Card, 1966). It seems, therefore, that both these types of relationship between volume and acid concentration may occur in a sufficiently large population.

When increasing volumes of saline were used to dilute the standard dose $(6 \mu \mathrm{g} . / \mathrm{kg}$.) of pentapeptide, the acid response to the pentapeptide decreased, presumably due to the differences in the degree of stimulation of the acid-secreting cells and the duration of the effect of the stimulus. The detection of the effect of depot volume by its influence on target organ response has not been previously recorded. Only one other report has noted the effect of volume of depot on the rate of absorption of injected material, but in that study clearance of radioactive sodium from muscle was measured by scanning the injection site (Warner, Dobson, Pace, Johnston, and Finney, 1953). The effect is presumably demonstrable only if the stimulus provided by the pentapeptide in the more dilute solution is submaximal and if reproducibility of response is of a very high order. Both of these criteria were fulfilled by four of our subjects. Failure to observe the effect in the other individual 
might mean that the depot effect is an artefact and, although this seems unlikely, larger numbers of subjects will have to be studied. The reversal of the 'depot' effect in this subject suggests that the effect of pentapeptide in small volumes might have been inhibitory, but inhibition of gastric response was not observed during the intravenous infusion when the concentration of pentapeptide was increased.

The inhibitory action of a relatively crude preparation of secretin in a dose of 25 units per kilogram per hour on the gastric response to subcutaneous pentapeptide is similar to the effect of secretin on gastric secretion stimulated by gastrin in dogs (Wormsley and Grossman, 1964). The failure of secretin to inhibit 'basal' gastric secretion cannot yet be explained.

Vagotomy decreased the gastric secretory response to subcutaneous pentapeptide in all our patients. The majority of subjects showed a decrease in acid output of $70 \%$ or more, with a marked reduction in acid concentration and decreased pepsin secretion. However, four of the patients secreted gastric juice of normal composition, although acid output was reduced compared with the preoperative values. Further studies are required to determine whether these two patterns are merely variants of the secretory response of the vagotomized stomach to pentapeptide or indicate gastric mucosal damage, or whether the difference in reaction to pentapeptide denotes differing degrees of cholinergicinnervation of the secreting cells of the stomach and relates better than the insulin test to the clinical postoperative course. We cannot explain why the stomach responds better to intravenous than to subcutaneous pentapeptide after vagotomy, since we do not know whether the gastric secretory cells are showing a change in responsiveness to direct stimulation by pentapeptide, or whether vagotomy has altered the conditions for release of a gastric secretory stimulant (such as acetylcholine) by pentapeptide.

\section{SUMMARY}

The gastric response to subcutaneous administration of a standard dose (6 $\mu \mathrm{g}$. per kilogram body weight) of a gastrin-like pentapeptide has been studied in normal subjects and patients with duodenal ulcer. The test has been found to give reproducible results both when repeated immediately and after a period of time. In view of the demonstrable effect of varying the volume of saline in which the pentapeptide is dissolved, it is necessary to standardize this factor when using subcutaneous pentapeptide to assess gastric secretion. The gastric response to pentapeptide was reduced by a continuous intravenous infusion of secretin in three subjects. Vagotomy reduced the gastric response to subcutaneous pentapeptide by over $50 \%$ in 11 of 12 patients and over $70 \%$ in eight.

We wish to thank Dr. Henry T. Howat for help in the preparation of this paper and for placing the resources of his unit at our disposal during these studies; Mr. H. B. Torrance for permission to study his patients; Dr. J. D. Fitzgerald (Medical Section, Pharmaceutical Division, Imperial Chemical Industries) for supplies of pentapeptide; and Dr. R. Ollerenshaw and the staff of the department of Medical Illustration, Manchester Royal Infirmary, for the figures. K.G.W. is receiving a full time research grant from the Medical Research Council.

\section{REFERENCES}

Hollander, F. (1952). Gastric secretion of electrolytes. Fed. Proc., 11, 706-714.

Hunt, J. N. (1948). A method for estimating peptic activity in gastric contents. Biochem. J., 42, 104-109.

Makhlouf, G. M., McManus, J. P. A., and Card, W. I. (1966). A quantitative statement of the two-component hypothesis of gastric secretion. Gastroenterology, 51, 149-171.

Pavlov, I. P. (1910). The Work of the Digestive Glands, Translated by W. H. Thompson, 2nd ed. Griffin, London.

Rosemann, R. (1907). Beiträge zur Physiologie der Verdauung. I. Die Eigenschaften und die Zusammensetzung des durch Scheinfütterung gewonnenen Hundemagensaftes. Arch. ges. Physiol., 118, 467-524.

Ward, S., Gillespie, I. E., Passaro, E. P., and Grossman, M. I. (1963). Comparison of histalog and histamine as stimulants for maximal gastric secretion in human subjects and in dogs. Gastroenterology, 44, 620-626.

Warner, G. F., Dobson, E. L., Pace, N., Johnston, M. E., and Finney, C. R. (1953). Studies of human peripheral blood flow: the effect of injection volume on the intramuscular radiosodium clearance rate. Circulation, 8, 732-734.

Wormsley, K. G., and Grossman, M. I. (1964). Inhibition of gastric acid secretion by secretin and by endogenous acid in the duodenum. Gastroenterology, 47, 72-81.

-, Mahoney, M. P., and Ng, M. (1966). Effects of a gastrin-like pentapeptide (ICI 50, 123) on stomach and pancreas. Lancet, 1, 993-996. 